Научная статья

УДК 658.1.001.76

DOI 10.18101/2304-4446-2021-1-80-85

\title{
ПЕРИОДИЗАЦИЯ ПРОЦЕССОВ ТРАНСФОРМАЦИИ ОТЕЧЕСТВЕННОГО СЕЛЬСКОГО ХОЗЯЙСТВА: КЕЙС БУРЯТИИ
}

\author{
(C) Цыренов Даши Дашанимаевич \\ Бурятский государственный университет имени Доржи Банзарова \\ Россия, 670000, г. Улан-Удэ, ул. Смолина, 24а \\ dashi555@mail.ru
}

\begin{abstract}
Аннотация. Сельскохозяйственное производство и аграрный сектор народного хозяйства в XX в. прошли большой этап становления и развития. На начальном этапе важно было определить специализацию огромных и многочисленных территориальных районов Советского государства, а с другой - начать процессы объединения и повсеместного кооперативного движения. Особенно сложно эти процессы происходили с кочевым и полукочевым населением Бурятии. На следующем этапе удалось организовать учет земельных наделов и сформировать условия труда для колхозников и механизаторов. В военное время перед отечественным аграрным сектором ставилась задача - обеспечить продовольствием фронт и тыл, а позднее - наверстать упущенные позиции как за счет электрификации, так и экстенсивного использования земли. В последние десятилетия меры Советского государства были направлены на улучшение других факторов производства — труда и капитала.

Ключевые слова: сельское хозяйство; трансформация; государственное управление; ретроспективный анализ; периодизация.
\end{abstract}

\section{Для цитирования}

Цыренов Д. Д. Периодизация процессов трансформации отечественного сельского хозяйства: кейс Бурятии // Вестник Бурятского государственного университета. Экономика и менеджмент. 2021. № 1. С. 80-85.

В развитии сельского хозяйства в Бурятии за 60-летний период времени с управленческой точки зрения можно выделить две основные модели организации сельскохозяйственного производства: 1) повсеместная индустриализация (20-50-е гг. XX в.); 2) крупномасштабное аграрное производство на основе повышения личной мотивации сельхозтоваропроизводителей (50-80-е гг. ХX в.). А с исторической точки зрения можно выделить 4 временных этапа, каждый из которых имеет свои специфические особенности.

Установление Советской власти и трансформация аграрного сектора (1917-1927 гг.)

Развитие сельских территорий и аграрного производства после установления Советской власти в октябре 1917 г. было трудным и противоречивым. Революция, социальные потрясения из-за гражданской войны, последствия развертки «военного коммунизма» - вот основные причины упадка отечественного сельскохозяйственного производства, проявившиеся в сокращении поголовья скота и посевных площадей. Объявленная колхозно-совхозная система привела к кризису индивидуальной хозяйственной инициативы. 
Д. Д. Цыренов. Периодизация процессов трансформации отечественного сельского хозяйства: кейс Бурятии

Становление светского государства, отказ от морально-этических норм христианства и других религий на территории Советского государства стали ключевыми причинами духовно-нравственного кризиса населения, особенно сельского, где многие циклы сельского уклада жизни были связаны с христианскими праздниками. К числу положительных сторон следует отнести наделение женской части населения земельными наделами, ограничение кулачества, обеспечение беднейших слоев крестьянства землей.

Не обошли стороной общие тенденции и Бурят-Монгольскую АССР (БМАССР), характеризующуюся повсеместным кочевым и полукочевым скотоводством, отставанием в земледельческом хозяйстве, примитивностью средств труда и форм организации аграрного производства. Первая пятилетка показала, что требуется «волевая рука государства» для выхода из системного кризиса.

Развертка нэп (новая экономическая политика на смену политики военного коммунизма) позволила органам на местах определять приоритеты в развитии аграрного производства. Интенсивно началось техническое вооружение сельских территорий и повсеместное развитие кооперативного движения в крестьянскофермерском классе.

В БМАССР оперативно решались вопросы по восстановлению поголовья скота, но требовалось соответствовать общим тенденциям в развитии земледелия. Для этого были созданы прообразы современных племенных хозяйств, организованы случные пункты во всех аймаках республики, проводились работы по отбору маточного поголовья скота для улучшения качества молока. Большое внимание было уделено вопросам ветеринарного контроля и обеспечения эпизоотического благополучия скота. Однако ограниченные финансовые ресурсы не позволяли содержать большой штат ветеринарной службы. В БМАСССР, как в целом и по всей стране, несмотря на усилия советской власти по коллективизации, на окраинных территориях продолжалось развитие индивидуально-крестьянского движения, которое, по сути, оставалось всё также мелкотоварным.

Организация первых коллективных хозяйств проводилась путем обычного соединения материального имущества и средств крестьян при использовании свободных участков земли, зачастую малопригодных для сельскохозяйственного оборота. Плотность колхозного движения отличалась по всей БМАССР: наибольшее развитие колхозы получили в экономически развитых районах, а наименьшее было характерно для сельских аймаков со специализацией на кочевом скотоводстве, а также районов компактного проживания семейского населения.

К исходу первой десятилетки БМАССР смогла достигнуть довоенных масштабов, а в ряде случаев - даже превзойти (например, по животноводству). Наиболее значимый прирост произошел в овцеводстве, что объясняется высокой плодовитостью и неприхотливостью в питании и уходе. Изменения в структуре растениеводства связаны с ростом площадей под посевы пшеницы, гречихи, проса и кормовых культур. Социальным итогом первой десятилетки советской власти стало осереднячивание и сокращение доли крайне богатых и крайне бедных крестьян.

Сельское хозяйство в 20-30-е гг. XX в.: формирование предвоенного базиса

Характерной чертой развития Советского государства в анализируемый период стала продолжающаяся коллективизация сельского хозяйства. Новым трендом, объявленным И. В. Сталиным в статье «Год великого перелома» (газета 
«Правда» № 259 от 7 ноября 1929 г.), становится масштабная кампания по развитию зернового хозяйства. Основным механизмом реализации хлебозаготовительной программы стала сплошная коллективизация. Так, было положено начало многолетней гонке в обобществлении крестьянских хозяйств.

Первая пятилетка в БМАССР предполагала полное завершение коллективизации, реализовать которую не получилось вследствие низких стартовых условий - более $90 \%$ аборигенного бурятского и тунгусского населения вело кочевой образ жизни, что никак не способствовало развитию земледелия. Политика раскулачивания, начатая большевиками в 1930 г., подстегнула рост коллективизации. Твердая, порой жестокая деятельность местных органов власти по реализации политики раскрестьянивания была осуждена И. В. Сталиным в статье «Головокружение от успехов. К вопросам колхозного движения» (газета «Правда» № 60 от 2 марта 1930 г.), что привело к снижению темпов коллективизации.

Новым инструментом коллективизации становится установление контрольных цифр - заданий по мотивированному втягиванию крестьян в колхозы. Благодаря этому становится меньше угроз и шантажа, административного давления, беззакония и произвола на местах. Все чаще применяются меры экономического стимулирования и поощрения коллективного ведения хозяйства.

Следующий виток коллективизации связан с начавшимся в 1931 г. «вторым этапом ликвидации кулачества как класса». В 1932-1933 гг. начинается чистка внутри самого колхозного движения - избавление от «классово-враждебных элементов». Ломка сложившегося уклада сельской жизни и традиционных форм организации хозяйственной деятельности вместе с тем не привела к сплошной коллективизации в Бурятии. К концу 1932 г. произошла смена 61,1 тыс. малых крестьянских хозяйств на 1,5 тыс. коллективных хозяйств.

Рост площади под посевы хлеба и связанное с этим отвлечение трудовых ресурсов от животноводства привели к катастрофическому снижению поголовья скота в Бурятии. К 1932 г. поголовье КРС к уровню 1929 г. сократилось почти вдвое (снижение на 57\%). Поголовье лошадей сократилось на $63 \%$, а коз и овец - на $27 \%$. Наложившееся уменьшение капитальных вложений в животноводство, диспаритет цен на продукцию промышленного и сельскохозяйственного производства, низкие закупочные цены еще больше ухудшили ситуацию.

В пространственном аспекте коллективизация в Бурятии происходила разными путями. Так, для западной части региона важной была интенсификация самой коллективизации, а для восточных аймаков - смена кочевого и полукочевого образа жизни на организацию оседлой жизни и ведения домашнего хозяйства. Переход от номадного уклада предполагалось осуществить за счет кооперирования вокруг молочного дела, овцеводства, коневодства и первичной переработки продукции животноводства. Финансовая и организационно-техническая поддержка от государства позволила осуществить перевод кочевников на оседлый образ жизни в сравнительно короткий период (1930-1935 гг.). Инфраструктуры вновь образованных поселений включала дома, бани, скотные дворы, овчарни, конюшни, ремонтные мастерские и пр. Позднее произошла смена мелких ремонтных мастерских на машинные сенокосные станции и машинно-тракторные станции. 
Д. Д. Цыренов. Периодизация процессов трансформации отечественного сельского хозяйства: кейс Бурятии

Обслуживание машинно-тракторных станций, ставших закономерным итогом сплошной коллективизации, потребовало подготовки нового класса работников на селе - механизаторских кадров. Для поддержки животноводства потребовалась широкомасштабная подготовка ветеринарных кадров.

Перевод кочевого населения на оседлый образ жизни обнажил проблему организации питания, стойлового ухода и содержания животных в зимний период времени. Для выхода из сложившейся ситуации было принято решение о наделении животноводства статусом основной отрасли сельского хозяйства в восточных аймаках и подчинить ее нуждам развитие растениеводства. А для западных аймаков была выбрана противоположная модель развития - ориентация на выращивание зерновых культур. К середине $30-\mathrm{x}$ гг. ХХ в. положение в аграрной сфере нормализовалось: колхозы и совхозы, как и задумывалось советской властью, стали основными производителями зерна и других культур, а пастбищнокочевое скотоводство вытеснено колхозным животноводством.

Развитие сельского хозяйства в предвоенный период происходило трудно и противоречиво. Так, колхозы перестали реализовывать кооперативные функции, теряя свои позиции в пользу совхозов, крестьяне в большинстве своем стали наемными рабочими, имеющими меньшую заинтересованность в общественном хозяйстве. С другой стороны, следует отметить и положительные результаты, к числу которых следует отнести организацию учета земельных наделов, формирование условий труда для колхозников и механизаторов, рациональное использование машинно-тракторного парка и завершение коллективизации крестьянских хозяйств.

\section{Аграрное производство в Бурятии: 40-60-е гг. XX в.}

Военное время наложило свой отпечаток на развитие сельскохозяйственного производства как в целом по стране, так и в Бурятии. Для подавляющего большинства колхозов характерно снижение темпов прироста объемов производимой продукции. В основу были заложены нормативы обязательных поставок продукции, закрепленные на каждый гектар обрабатываемых земель.

Ситуация в военные годы (1941-1945) фактически походила на период продразверсток времен гражданской войны, поскольку для обоих случаев характерно изъятие максимально возможного, а зачастую и посевного материала, что не обеспечивало минимального простого воспроизводства. Кроме обязательных поставок сельскохозяйственной продукции в стране была развернута кампания по добровольным сборам, которая не обошла стороной и сельские территории: в фонд обороны, на строительство, семьям фронтовиков и инвалидам боевых действий и т. д. Фонд обороны, например, пополнялся за счет переработки трудодней с соответствующим приростом производимой продукции и последующим перечислением пожертвований, как в денежной, так и натуральной форме.

Для поддержки личных подсобных хозяйств было принято решение о передаче части земель с согласия колхозов в индивидуальное пользование. Это помогло как избежать голода, так и повысить сбор налоговых отчислений из денежных платежей населения.

Война изменила структуру трудовых ресурсов, занятых в сельскохозяйственном производстве. Так, здесь возросла доля женщин, а также молодежи и детей. В целом снизился уровень квалификации работников, занятых в аграрной сфере. 
Залогом успешного выполнения поставленных планов по сбору продукции сельского хозяйства стал соревновательный характер, что выразилось в росте среднегодовой выработки трудодней. Благодаря социалистическому соревнованию был обеспечен необходимый минимум продовольствия в военное время. Дух соперничества позволил в первую пятилетку после войны достигнуть и превзойти довоенный уровень по поголовью овец и коз в Бурятии. Однако восстановить поголовье КРС не удалось, также как и повысить продуктивность скота.

Для послевоенного времени характерно укрепление материально-технической базы аграрного производства. Началась повсеместная электрификация сельскохозяйственных заимок и других объектов.

На пленуме ЦК КПСС (сентябрь 1953) дана переоценка действий и результатов колхозов и совхозов. Впервые был поднят вопрос о материальной мотивации работников, занятых в сельском хозяйстве, в развитии производства и росте его прибыльности.

В 1594-1965 гг. начался комплекс мероприятий по росту производства зерна в СССР. Для этого были введены в оборот обширные целинные и залежные земельные ресурсы. Экстенсивный прирост позволил увеличить производство продукции растениеводства. Вместе с тем исчерпание естественного плодородия целины, дефицит вносимых минеральных удобрений, наметившийся тренд урбанизации и сокращение доли сельского населения - все это сигнализировало о появлении кризисных явлений в сельском хозяйстве.

Сельскохозяйственное производство в 1965-1985 гг.

На пленуме ЦК КПСС (март 1965 г.) были внесены трансформационные изменения в концепцию хозяйственного механизма. На ближайший период были определены планы продажи произведенной продукции, которые стали теперь неизменными. Большим достижением того времени можно считать внедрение механизма системы надбавок за сдачу сверхплановой продукции. Другой важной особенностью является реализация инструментов повышения материального уровня жизни колхозников - для этого были сняты ограничения с использования ЛПХ.

В анализируемый период времени продолжилась работа по формированию отраслевых и территориально-отраслевых межхозяйственных объединений. Основной упор был сделан на таких подотраслях, как птицеводство и овощеводство, в которых результаты кооперирования могут быть получены быстрее (в пределах одного-двух календарных лет). На практике реализация этой идеи привела к доминированию государственной собственности, а не планируемого межхозяйственного подхода.

Для Бурятии данный период ознаменовался существенным обновлением машинно-тракторного парка за счет интенсивных финансовых вливаний в колхозно-совхозную систему. Значительные капитальные вложения позволили начать повсеместную механизацию, мелиоративную обработку земель сельскохозяйственного назначения, внедрение механизмов селекционного отбора наиболее продуктивных пород скота и сортов растений.

Общий рост образованности населения страны позволил увеличить долю специалистов с высшим и средним специальным образованием, в том числе и в отечественном сельском хозяйстве. Данный факт послужил основным фактором пе- 
Д. Д. Цыренов. Периодизация процессов трансформации отечественного сельского хозяйства: кейс Бурятии

рехода от экстенсивного к интенсивному росту производительности труда и производства продукции аграриев в целом. Более высокий уровень образования привел также к коренным изменениям в быту трудящихся, в их укладе жизни, в сознании людей.

\section{Заключение}

Система государственного управления развитием сельскохозяйственного производства в Советском государстве прошла разные этапы в своем развитии. Неизменным осталась основная цель - обеспечение и повышение продовольственной безопасности страны. Достижение цели обеспечивалось разными экономическими инструментами и механизмами - начиная от процессов коллективизации, разработки инструментов мотивации аграриев, улучшения условий трудящимся, завершая значительными финансовыми вливаниями, повсеместной электрификацией и механизацией труда.

\section{Литература}

1. Краусп В. Р. История развития электрификации и автоматизации АПК. К 85-летию ВИЭСХ // Вестник ВИЭСХ. 2015. № 2(19). С. 3-10.

2. Полушкина Т. М. Опыт реформирования отечественного сельского хозяйства: критический анализ // Фундаментальные исследования. 2013. № 1-2. С. 499-503.

3. Тубалец А. А., Лиовская Р. Н., Толмачев А. В. Ретроспектива развития и регулирования малых форм производства // Политематический сетевой электронный научный журнал Кубанского государственного аграрного университета. 2015. № 108. С. 654-668.

4. Ценч Ю. С., Маслов Г. Г., Трубилин Е. Г. К истории развития сельскохозяйственной техники // Вестник Башкирского государственного аграрного университета. 2018. № 3(47). C. 117-123.

Статья поступила в редакцию 30.12.2020; одобрена после рецензирования 28.01.2021; принята к публикациии 29.01.2021.

\section{PERIODIZATION OF TRANSFORMATION PROCESSES \\ IN DOMESTIC AGRICULTURE: THE CASE OF BURYATIA}

Dashi D. Tsyrenov

Dorzhi Banzarov Buryat State University

24a Smolina St., Ulan-Ude 670000, Russia

dashi555@mail.ru

Agricultural production and the agrarian sector of the national economy in the $20^{\text {th }}$ century underwent a stage of competitive enhancement. At the initial stage, it was important to determine the specialization of the huge numerous territorial regions of the Soviet state, and to begin the processes of unification and widespread cooperative movement. These processes were especially complex in Buryatia with the nomadic and semi-nomadic population. At the next stage, it was possible to organize the registration of land allotments and create conditions for the work of collective farmers and machine operators. In wartime, the domestic agricultural sector was faced with the task of providing food to the front and rear, later the sector should made up for lost ground both by means of electrification and extensive land use. In the last decades the efforts of the Soviet state were aimed at improving other factors of production - labour and capital.

Keywords: agriculture; transformation; public administration; retrospective analysis; periodization. 